\title{
ПРАВО
}

LAW

УДК 343.533(5-012)

DOI dx.doi.org/10.24866/1813-3274/2020-2/107-124
А. В. Даниловская ${ }^{1}$
Хабаровский государственный университет экономики и права,
г. Хабаровск, Россия
E-mail: d_a_v@list.ru

\section{ПРАВОВАЯ ЗАЩИТА КОНКУРЕНЦИИ В ЯПОНИИ, РЕСПУБЛИКЕ КОРЕЯ И КИТАЙСКОЙ НАРОДНОЙ РЕСПУБЛИКЕ: ОСОБЕННОСТИ УГОЛОВНОЙ ОТВЕТСТВЕННОСТИ}

Аннотация: Антимонопольное регулирование, противодействие картелям и недобросовестной конкуренции являются одними из актуальных направлений государственной политики во всех странах с рыночной экономикой или переходящих к таковой. Среди них - Япония, Республика Корея и КНР - страны, каждая из которых имеет сложившуюся и развивающуюся систему нормативных правовых актов, направленных на защиту конкуренции. Антимонопольное и конкурентное законодательство этих стран построено с учетом мирового опыта противодействия различного рода ограничениям конкуренции, имеет в своем арсенале разные способы защиты, включая программы смягчения ответственности хозяйствующих субъектов при их активном содействии раскрытию нарушений. Уголовно-правовые средства противодействия ограничениям конкуренции существуют во всех рассматриваемых юрисдикциях. При этом уголовная ответственность наступает за широкий перечень нарушений. Помимо наказаний в виде лишения свободы (с принудительным трудом или без такового) и (или) штрафов в ряде случаев предусмотрена конфискация преступного дохода. Анализ антимонопольного, конкурентного законодательства и

\footnotetext{
${ }^{1}$ Анна Владимировна Даниловская, кандидат юридических наук, доцент юридического факультета Хабаровского государственного университета экономики и права, докторант Дальневосточного федерального университета, г. Владивосток, г. Хабаровск, Россия.

Для циитирования: Даниловская А. В. Правовая защита конкуренции в Японии, Республике Корея и Китайской Народной Республике: особенности уголовной ответственности // Азиатско-Тихоокеанский регион: экономика, политика, право. 2020. № 1. С. 107-124.
}

(C) Даниловская А. В., 2020 
уголовного законодательства этих стран представляет как научный, так и практический интерес для российского законотворчества и правоприменения.

Ключевые слова: антимонопольное и конкурентное законодательство Японии, Республики Корея, КНР, УК Японии, УК Республики Корея, УК КНР, противодействие ограничениям конкуренции, уголовная ответственность, картель, недобросовестная конкуренция, недобросовестная торговая практика, программа смягчения ответственности.

\section{Anna V. Danilovskaya ${ }^{1}$}

Khabarovsk State University of Economics and Law, Khabarovsk, Russia

E-mail: d_a_v@list.ru

\section{LEGAL PROTECTION OF COMPETITION IN JAPAN, THE REPUBLIC OF KOREA AND THE PEOPLE'S REPUBLIC OF CHINA: FEATURES OF CRIMINAL LIABILITY}

Abstract. Antitrust regulation, countering cartels and unfair competition are one of the most important areas of government policy in all countries with a market economy or those that are moving to it. Among them there is Japan, the Republic of Korea and the PRC - the countries with established and developing systems of regulatory legal acts aimed at protecting competition. The antitrust and competition laws of these countries are built taking into account the international experience in countering various kinds of competition restrictions and have various protection methods in their arsenal, including the programs to mitigate the responsibility of economic entities with their active assistance in disclosing violations. Criminal remedies to counter competition restrictions exist in all jurisdictions in question. Moreover, criminal liability arises for a wide range of violations. In addition to the punishments of imprisonment (with or without forced labor) and / or fines, in some cases, the confiscation of criminal income is stipulated. The analysis of the antitrust, competition and criminal laws of these countries is of both scientific and practical interest for Russian lawmaking and law enforcement.

Keywords: antitrust and competition laws of Japan, the Republic of Korea, China, the Criminal Code of Japan, the Criminal Code of the Republic of Korea, the Criminal Code of the People's Republic of China, anti-competitive restrictions, criminal liability, cartel, unfair competition, unfair trade practices, a mitigation program.

\footnotetext{
${ }^{1}$ Anna V. Danilovskaya, Ph.D. (Law), associate professor of the Faculty of Law, Khabarovsk State University of Economics and Law, doctoral student at the Far Eastern Federal University, Vladivostok, Khabarovsk, Russia.

For citing: Danilovskaya A. V. Legal protection of competition in Japan, the Republic of Korea and the People's Republic of China: features of criminal liability // PACIFIC RIM: Economics, Politics, Law. 2020. No 1. P. 107-124.
} 
Отношение азиатских стран к злоупотреблению доминирующим положением, картелям, формам недобросовестной конкуренции, несмотря на различия в правовых системах и путях развития внутренних экономик, не является принципиально отличным - их законодательство построено на традиционных экономических ценностях - защите конкуренции, прав потребителей, недопущении недобросовестных практик.

Антимонопольное законодательство и уголовная ответственность за его нарушения первыми из трёх рассматриваемых стран появились в Японии, на их становление и первоначальное развитие существенное влияние оказало антитрестовское законодательство и судебная практика США: после Второй мировой войны США приняли непосредственное участие в определении направлений японской антимонопольной политики [1, с. 66, 68].

Основу антимонопольного и конкурентного законодательства Японии составляют Закон «О запрете частной монополии и поддержании добросовестной торговли» (далее - антимонопольный закон), принятый в 1947 г. [2], и Закон «О предотвращении недобросовестной конкуренции» 1993 г. [3].

Антимонопольный закон Японии содержит запреты и положения об уголовной ответственности за их нарушение с перечислением конкретных составов преступлений и наказаний за их совершение. В частности, в нём выделяются такие виды противоправных действий, как частная монополизация, необоснованное ограничение торговли, антиконкурентные нарушения в деятельности торговых ассоциаций, противоправная экономическая концентрация и недобросовестная деловая практика.

Уголовной ответственности подлежат не все из перечисленных видов действий. В частности, уголовно-правовые запреты не распространяются на недобросовестную деловую практику. В то же время, в первую очередь запрещены частная монополизация и необоснованное ограничение торговли. Под частной монополизацией в законе понимается такая деловая деятельность, при которой предприятие, индивидуально или совместно с другими предприятиями, исключает или контролирует деловую деятельность других предприятий, тем самым вызывая, вопреки общественным интересам, существенное ограничение конкуренции в любой конкретной области торговли. Необоснованное ограничение торговли означает деловую деятельность, при которой предприятия совместно устанавливают, поддерживают или повышают цены или ограничивают производство, технологии, продукты, услуги или контрагентов, тем самым вызывая, вопреки общественным интересам, существенное ограничение конкуренции в любой конкретной области торговли (ст. 2 закона). К таковой, в частности, относится картель [4]. Но, несмотря на его общий запрет (ст. 3), есть ряд исключений, при которых картель признается допустимым, например, разрешены картели в сфере авиаперевозок, страхования в авиационном и ядерном бизнесе [5]. 
Согласно гл. XI «Уголовные положения» антимонопольного закона уголовную ответственность влекут следующие деяния (ст. 89-91-2 закона): частная монополизация и необоснованное ограничение торговли, существенное ограничение торговой ассоциацией конкуренции в любой конкретной отрасли торговли, неисполнение вступившего в законную силу решения Комиссии по справедливой торговле (антимонопольного органа Японии, далее - Комиссия) о принятии рекомендательных мер в отношении правонарушителей, приобретение и владение акциями крупными предприятиями с нарушением требований закона, приобретение акций компаний с целью ограничения конкуренции, приобретение финансовой компанией $5 \%$ общего количества выпущенных акций другой компании и владение ими более года без предупреждения об этом Комиссии, совмещение лицом должностей в компаниях, находящихся в конкурентных отношениях между собой без уведомления об этом Комиссии, непредоставление информации или предоставление ложной информации Комиссии в случаях, установленных законом. Наиболее сурово наказывается нарушение запрета на частную монополизацию, необоснованное ограничение торговли и ограничение конкуренции торговой ассоциацией - перечисленные деяния влекут лишение свободы на срок до 5 лет или штраф до 5 млн иен, наказуемо также покушение на эти деяния.

Уголовная ответственность наступает и за различного рода иные нарушения при проведении расследования Комиссией по делам, возбужденным в отношении хозяйствующих субъектов (ст. 93-95-2).

Признаки преступлений не содержат специальных указаний на причинение ими определённого ущерба, т.е. можно сказать, что составы указанных преступлений сформулированы как формальные. Субъектами ответственности являются как физические, так и, в ряде случаев, юридические лица. В антимонопольном законе довольно подробно перечислены признаки субъекта - физического лица, им, в частности, являются должностное лицо или управляющий соответствующей торговой ассоциацией или её составляющего предприятия (включая должностное лицо, работника, агента или другое лицо, которое участвовало в действии в интересах предприятия, являлось учредителем предприятия), которое не приняло необходимых мер для предотвращения нарушения, несмотря на знание плана нарушения, или потерпевшего неудачу в принятии таких мер для устранения нарушения, несмотря на то, что ему известно о нарушении.

В антимонопольной практике Японии выявляется сравнительно небольшое количество нарушений. Так, в 2017 г. Комиссией по справедливой торговле было расследовано 143 случая нарушений антимонопольного законодательства; из них было выявлено 11 картелей, 1 случай недобросовестной торговой практики, в 2016 г. - 128 нарушений, из них 9 - картелей, 2 - недобросовестной торговой практики; 33 хозяйствующих субъекта были привлечены к ответственности и лишь не- 
которые - к уголовной с наказанием в виде штрафов [6]. В 2015 г. расследовано 123 нарушения, из них 7 - картели и 2 - недобросовестная торговая практика, в 2014 г. выявлено: 7 - картели, 2 - недобросовестная торговая практика, в 2013 г. 17 - картелей и 1 - недобросовестная торговая практика [7].

В соответствии с программным заявлением Комиссии, привлечение к уголовной ответственности в основе имеет только серьёзные нарушения законодательства в виде картелей, которые затрагивают жизнь широкого круга людей, повторных правонарушителей или правонарушителей, отказывающихся выполнять административные приказы Комиссии [8]. При этом наказание в виде лишения свободы, хотя и предусмотрено законом, практически не применяется [5].

С 2006 г. в Японии действует программа смягчения ответственности, в соответствии с которой до пяти компаний могут получить освобождение от выплаты так называемого оборотного штрафа или снижение его размера при подаче ими заявления о снисхождении (ст. 7-2 антимонопольного закона). При этом большое значение имеет время подачи заявления - компания, сделавшая это первой и до проведения проверки уполномоченным органом власти, имеет право на 100\% освобождения от любых штрафов, вторая - на 50\%, оставшиеся три - на 30\%, но четвёртая и пятая для получения возможности уменьшить размер штрафа обязаны предоставить материалы, которые не были известны Комиссии. В случае подачи заявления после начала расследования компания может рассчитывать лишь на $30 \%$ снижения безотносительно к очерёдности (а это только три компании) и при условии предоставления доказательств картеля, о которых Комиссия не была осведомлена.

Второй важный документ Японии, направленный на противодействие нарушениям в сфере конкуренции, - Закон «О предотвращении недобросовестной конкуренции». Помимо традиционных, в целом, критериев противодействия недобросовестной конкуренции, в нём содержатся положения об основаниях уголовной ответственности, наказаниях и иных мерах уголовно-правового характера (гл. 5 закона). В частности, предусмотрены составы преступлений, связанные с нарушением режима коммерческой тайны, противоправным использованием торгового обозначения, товарного знака, маркировки, упаковки, схожих до степени смешения с товарным видом или торговым обозначением иного лица и известных потребителю как принадлежащие иному лицу, а также распространением ложных сведений, приносящих ущерб репутации иного лица, являющегося конкурентом, с распространением ложных сведений о месте происхождения, качестве, содержании товаров, услуг.

Составы преступлений, образующих недобросовестную конкуренцию, в отличие от антимонопольных правонарушений, являются материальными и предусматривают последствия в виде ущерба, причинённого потерпевшей стороне. Также они характеризуются подробным описанием способов совершения деяния. Например, признаками объективной стороны нарушения режима коммерческой 
тайны, которое признаётся наиболее опасным преступлением, является совершение его посредством мошенничества, угроз, кражи активов, несанкционированного доступа, включая доступ к компьютеру, незаконного присвоения носителя записи или объекта, содержащих сведений, составляющих коммерческую тайну, воспроизведения описания или записи с носителя и др. Деяния, содержащие признаки преступного нарушения режима коммерческой тайны, помимо наказания в виде лишения свободы на срок до 10 лет с обязательными работами и (или) штрафом до 20 млн иен, влекут конфискацию дохода, полученного в результате таких преступлений (ст. 21 п. 10-12). Кроме того, в законе особо оговаривается экстерриториальность действия уголовно-правовой нормы об ответственности за эти преступления, нарушающие режим коммерческой тайны (ч. 3 ст. 21 закона), а также ответственность за покушение на эти преступления (ч. 4 ст. 21 закона).

Субъектами уголовной ответственности за рассматриваемые преступления в Японии являются физические лица, к которым законом отнесены представители корпорации, работники корпорации и любые иные лица, а также юридические лица, на которые закон налагает наказание в виде штрафа (ст. 22).

В силу особенности японской правовой системы, антимонопольное законодательство Японии является источником уголовного права наряду с УК Японии, который не содержит специальных составов преступлений против конкуренции [9]. Анализ содержания УК Японии приводит к выводу, что в нём имеется описание лишь одного преступления, чей состав заслуживает внимания в целях применимости его в противодействии ограничению конкуренции, - нарушения на торгах (ст. 96-П1). Признаки состава преступления заключаются в нарушении справедливости торгов путём обмана или влияния (ч. 1) и сговоре, подрывающем справедливую цену, с целью получения необоснованной выгоды. В качестве наказания предусмотрено лишение свободы с принудительным трудом на срок до 2 лет или денежным штрафом на сумму до 2 млн 500 тыс. иен. Статья 96-П1 содержится в гл. 5 «Преступления, состоящие в препятствовании исполнению публичных обязанностей», а значит объект преступления имеет публично-правовую характеристику. В связи с тем, что рассмотренный состав преступления содержится в УК Японии, а не в антимонопольном законе, есть основания предположить, что данный вид деяния не образует картель, а представляет собой иное преступление.

В Республике Корея долгое время отсутствовало антимонопольное законодательство. Совершенствование корейской экономики в первое время после окончания Второй мировой войны было связано с полным государственным регулированием, которое было промонопольным - монополиям предоставлялись приоритетное субсидирование, налоговые и другие льготы через банки, которые контролировались ими на определённых условиях [10, с. 33-38]. Однако в 80-х гг. характер экономической политики страны изменился в пользу более сбалансированного раз- 
вития, усиления действий рыночных сил и ограничения прямого государственного вмешательства.

Антимонопольное законодательство Южной Кореи включает в себя ряд документов, основным среди которых является Акт «О монопольном регулировании и справедливой торговле» 1980 г. [11] (далее - антимонопольный акт), содержащий множество запретов и уголовную ответственность за их нарушение. В частности, актом запрещены злоупотребление доминирующим положением (ст. 3-2), приобретение компанией в собственность акций присоединённой компании (ст. 9), долговые гарантии для присоединённых компаний (ст. 10-2), антиконкурентные совместные действия и соглашения (ст. 19), недобросовестная торговая практика (ст. 23).

Статьёй 19 антимонопольного акта запрещаются любые объединения хозяйствующих субъектов - контракт, соглашение, решение или любое иное средство совместного участия хозяйствующих субъектов, которые незаконно ограничивают конкуренцию действиями, указанными в данной статье. По сути такие соглашения образуют картель, хотя в самом акте этот термин не употребляется. Здесь же предусмотрены и исключения из запрета на соглашения, если несправедливые совместные действия признаются удовлетворительными и имеющими цели модернизации промышленности, исследования и развития технологий, преодоления экономического спада, промышленного реструктурирования, модернизации торговли, повышения конкурентоспособности малого и среднего бизнеса.

Помимо этого важное значение имеет совокупная доля компаний, участвующих в картеле, - если она не превышает 20\%, то Комиссия по справедливой торговле (антимонопольный орган Кореи имеет название, аналогичное японскому, далее - Комиссия) завершит проверку за отсутствием антиконкурентного эффекта или же его малозначительности. Такая оговорка в отношении картелей является весьма важной, т.к. позволяет отграничить действительно опасные антиконкурентные соглашения, требующие государственного вмешательства, от незначительных объединений, хотя бы и имеющих цель ограничить конкуренцию.

Между тем, правоприменение в Корее сконцентрировано на выявлении сговоров на торгах, которые запрещены той же ст. 19, и картелей с международным участием. По указанным нарушениям в 2018 г. Комиссия расследовала 134 случая соглашений [12]. Участие в сговоре на торгах может обернуться для хозяйствующего субъекта ограничением в дальнейшем его права участия в торгах на определённый срок по запросу Комиссии, адресованному уполномоченному органу государственной власти [13].

В Корее существует программа смягчения ответственности, предусмотренная ст. 22-2 антимонопольного акта, согласно которой при определённых условиях происходит смягчение или полное освобождение от ответственности хозяйствующих субъектов, сообщивших о своём участии в нарушении антимонопольного акта, 
в частности, о картеле. Комиссия предоставляет первому заявителю полный иммунитет от штрафов, которым подвергаются нарушители, а также по своему усмотрению может принять решение о предоставлении полного иммунитета от уголовного преследования, обеспечивая на практике неприкосновенность [13].

При этом заявитель должен соблюсти ряд условий для применения к нему программы смягчения. В их числе - предоставление Комиссии ранее неизвестной информации о картеле, добросовестное сотрудничество по всем вопросам до конца расследования, прекращение участия в картеле. Получить статус снисхождения могут и другие участники картеля при соблюдении предусмотренных антимонопольным актом требований. При этом принятие решения о снижении наказания на 50\% для второго заявителя является исключительной прерогативой Комиссии, так же как и иммунитет от уголовного преследования.

Нормы об уголовной ответственности за нарушение запретов антимонопольного акта содержатся в его гл. 14. Так, в соответствии со ст. 66 являются наиболее опасными и наказываются лишением свободы на срок до 3 лет или штрафом на сумму до 200 млн вон следующие деяния: злоупотребление предпринимателем своим доминирующим положением, подавление конкуренции в какой-либо сфере экономической деятельности индивидуально или совместно с иными хозяйствующими субъектами, осуществление в составе холдинговой компании запрещённых антимонопольным актом действия (например, приобретение акций отечественных компаний с целью контроля), учреждение холдинговой компании с нарушением требований, воспрепятствование расследованию и некоторые иные. Согласно ст. 67 антимонопольного акта наказываются лишением свободы на срок до 2 лет или штрафом до 150 млн вон несправедливая торговая практика, ограничение доступа на рынок другим хозяйствующим субъектам или их устранение с рынка, неисполнение предписаний Комиссии.

Субъектом уголовной ответственности за нарушения антимонопольного законодательства могут быть как физические, так и юридические лица. Так, в силу ст. 70 антимонопольного акта, в ряде установленных ею случаев - при злоупотреблении доминирующим положением, противоправном объединении предприятий, несправедливой торговой практике, включая картели, непредоставлении отчётов или предоставлении ложных сведений и некоторых иных (ст. 66-68) - уголовная ответственность в виде штрафов также возлагается на соответствующие юридические лица.

Противодействовать недобросовестной конкуренции в Республике Корея призван Закон «О предотвращении недобросовестной конкуренции и защите коммерческой тайны» [14]. Закон предусматривает основания уголовной ответственности за нарушение довольного широкого перечня запретов, относящихся к недобросовестной конкуренции. Таковыми являются посягательства на коммерческую тайну, акт смешения с товарами другого лица с использованием средств индивидуали- 
зации, упаковки, схожих со средствами индивидуализации, упаковкой другого лица, известного в Республике Корея, акт смешения с коммерческими объектами другого лица или действия со знаками, идентичными знакам, принадлежащим известному в Республике Корея иному лицу, причинение ущерба репутации другого лица путём использования идентичных с ним знаков, торгового наименования, товарного знака, упаковки при распространении товаров с такими обозначениями и некоторые другие. Все деяния наказываются лишением свободы на разные сроки (максимальное - 10 лет) и (или) штрафами. Нарушение режима коммерческой тайны, так же как и в Японии, признано наиболее опасным преступлением, в связи с чем предусмотрена ответственность за покушение на него (ст. 18-2) и за его совершение группой лиц (ст. 18-3).

Направлен на поддержание справедливой торговли в Южной Корее и Закон «О справедливой маркировке и рекламе» [15], также предусматривающий составы преступлений и ответственность за нарушения в регулируемой сфере. В частности, гл. 5 «Уголовное обеспечение» предусматривает уголовную ответственность за размещение ложной рекламы, несоблюдение требований Комиссии в случаях, предусмотренных законом (согласно ч. 1 ст. 17 наказывается лишением свободы сроком до 2 лет или штрафом в размере до 150 млн вон).

Содержит основания уголовной ответственности, которые могут быть применимы для борьбы с ограничением конкуренции, и УК Республики Корея, однако их круг весьма ограничен. Так, к ним можно отнести преступления, предусмотренные ст. 314 «Препятствия в бизнесе», ст. 315 «Препятствия на торгах» гл. 34 «Преступления против кредита, бизнеса и аукциона», а также ст. 317 «Профессиональное раскрытие секретов других» гл. 35 «Преступления, связанные с нарушением тайны». Нарушения на торгах признаются одним из традиционных антиконкурентных нарушений, и потому представляет интерес совокупность признаков преступления, закреплённая в УК Республики Корея. В нём они описаны как препятствование в проведении беспристрастных торгов, осуществлённое обманными средствами или угрозой силы либо другими способами, и подлежит наказанию в виде каторжных работ на срок не более 2 лет или штрафа в размере не более 7 млн вон. Очевидно, что речь в данном случае идёт не о сговоре на торгах, и, следовательно, необходимо отличать этот состав преступления от сговора на торгах, образующего картель, который также влечёт уголовную ответственность, но не в соответствии с УК Кореи, а антимонопольным актом.

Из анализа японского и корейского законодательства видно, что противодействие ограничению конкуренции в этих странах имеет много общего. Кроме уже отмеченного, сходства также заключаются в том, что, во-первых, уголовной ответственности подлежат лица, как умышленно, так и по неосторожности нарушившие антимонопольное и конкурентное законодательство; во-вторых, возмещение ущер- 
ба потерпевшим хоть и является обязательным, но при этом не относится к условиям применения программы смягчения ответственности, как это существует в российском законодательстве, что существенно затрудняет, а порой делает невозможным применение программы смягчения ответственности (к слову, программа смягчения в обеих странах - а в общем это и мировая тенденция - постоянно совершенствуется, она весьма востребована в связи с угрозой уголовного преследования за картель); в-третьих, и в Японии, и в Южной Корее прокуратура обладает процессуальными полномочиями при возбуждении уголовного дела по фактам картелей и предъявлении обвинения виновным в этом лицам. И здесь также возможны изменения в целях ускорения процесса расследования уголовных дел в отношении рассматриваемой группы преступлений [13].

Законодательство КНР в сфере конкуренции, как и южнокорейское, начало формирование лишь в 80-х гг. и в настоящее время включает в себя ряд нормативных правовых актов, среди которых традиционно выделяются акты антимонопольного регулирования и против недобросовестной конкуренции. К первой группе относится Закон КНР «О противодействии монополиям» 2007 г. [17], ко второй - Закон КНР «О недобросовестной конкуренции» 1993 г. [18], Закон КНР «О рекламе» 1992 г. [19] и Закон КНР «О торговых марках» 1984 г. [20].

Закон «О противодействии монополиям» запрещает монополистические соглашения, злоупотребление доминирующим положением и осуществление концентрации экономической власти (без специального разрешения уполномоченных органов власти), образующие формы монополистической деятельности, а также злоупотребление полномочиями органами власти (администрациями) и организациями, осуществляющими управление общественными делами. Последняя форма нарушений неизвестна японскому и корейскому праву, но имеет аналог в российском. В целом, преследование за нарушения данного закона носит административный характер.

Монополистические соглашения в КНР понимаются широко - к ним отнесены как соглашения, решения, так и иные координированные действия, исключающие или ограничивающие конкуренцию (ст. 13 закона). Под это описание попадают и картели. Особо оговаривается запрет на организацию заключения соглашений отраслевыми ассоциациями. Однако следует отметить, что уголовная ответственность за картели в КНР не предусмотрена.

Между тем на монополистические соглашения, в т. ч. на картели, в КНР распространяется программа смягчения ответственности, установленная ст. 46 Закона «О противодействии монополиям». В соответствии с ней антимонопольный орган КНР может снизить размер штрафа или полностью освободить от него хозяйствующий субъект, который предоставит информацию о картеле и существенные тому доказательства. В отсутствие уголовной ответственности за картели, программа 
имеет значение при привлечении виновных хозяйствующих субъектов к административной ответственности и наложении на них «оборотных» штрафов.

Запрещая злоупотребление административными полномочиями органами власти и организациями, уполномоченными осуществлять регулирование общественных дел (гл. 5 названного закона), закон, во-первых, устанавливает общий запрет на такие действия, способные в явной или скрытой форме ограничивать осуществление организациями и частными лицами хозяйственной деятельности, а вовторых, перечисляет конкретные случаи злоупотребления полномочиями указанными органами и организациями. К последним, в частности, отнесены действия или акты, которые в названных в законе формах могут повлиять на конкуренцию, например, препятствие свободному обращению товаров между различными регионами, установление дискриминационных мер при проведении торгов, принуждение участников хозяйственной деятельности к осуществлению монополистической деятельности, указанной в законе, и некоторые иные.

Многочисленные формы недобросовестной конкуренции названы в Законе КНР «О недобросовестной конкуренции». Помимо её традиционного содержания, связанного с неправомерным использованием объектов интеллектуальной собственности, введением в заблуждение, использованием чужой коммерческой тайны, подрывом деловой репутации конкурента, недобросовестная конкуренция может быть в таких формах, как: ограничение хозяйствующими субъектамимонополистами покупателей условиями закупки у указанных ими хозяйствующих субъектов, в целях лишения последних возможности осуществления своей деятельности, тайный подкуп покупателей (как юридических, так и физических лиц) при купле-продаже товаров, продажа товара ниже себестоимости (за исключением предусмотренных законом случаев - п. 13), сговор на торгах в целях поднятия или снижения стоимости предмета торгов (п. 15). Примечательно, что сговор на торгах относится именно к недобросовестной конкуренции, в отличие от законодательства большинства стран, в соответствии с которым сговор на торгах - это антиконкурентное соглашение (картель), форма монополистической деятельности.

Некоторые положения Закона КНР «О недобросовестной конкуренции» носят бланкетный характер, отсылая, в частности, при неправомерном использовании чужих прав на товарный знак, к Закону КНР «О торговых марках». Последним же определяются виды ответственности за данные правонарушения, включая уголовную.

Закон КНР «О рекламе» напрямую не относит нарушения в сфере рекламной деятельности к недобросовестной конкуренции, но содержит ряд запретов рекламы, распространение которой может непосредственно нарушить интересы конкурентов, в частности, запрещено в рекламе принижение качества товаров и услуг других хозяйствующих субъектов (ст. 12). 
Все нормативные правовые акты КНР в сфере защиты конкуренции содержат описание признаков составов преступлений. Между тем УК КНР, являющийся согласно его ст. 3 единственным законом, определяющим преступные деяния [21], либо не подтверждает уголовно-правовой запрет, установленный специальным законом, либо предусматривает составы преступлений только отчасти аналогичные тем, что содержатся в антимонопольном и конкурентном законодательстве. Так, согласно Закону КНР «О противодействии монополиям» уголовная ответственность наступает при наличии признаков двух составов преступлений: 1) отказ в предоставлении материалов и информации или предоставление фальсифицированных материалов и ложной информации или сокрытие, уничтожение, перемещение доказательств или иных действий по препятствованию в рассмотрении дела и проверки, осуществляемой правоприменительной структурой по противодействию монополиям (ст. 52), 2) злоупотребление полномочиями, пренебрежение должностными обязанностями, использование служебного положения в корыстных целях, раскрытие коммерческой тайны, полученной в ходе правоприменительного процесса сотрудниками правоприменительной структуры по противодействию монополиям (ст. 54). Однако УК КНР напрямую таких составов преступлений не предусматривает. Лишь деяния, запрещённые ст. 54 закона, могут быть квалифицированы по двум статьям УК - ст. 397 «Злоупотребление должностными полномочиями» или ст. 219 «Посягательство на коммерческую тайну».

Содержит основания уголовной ответственности и Закон КНР «О рекламе», но не все из них были так же воспроизведены в УК КНР. Так, реклама, противоречащая установленным в ст. 7 закона стандартам, - служить духовному и физическому оздоровлению народа, способствовать повышению качества товаров и услуг, защищать законные интересы потребителей, придерживаться общественной и профессиональной этики, охранять престиж и интересы государств, либо использующая государственные символы КНР, наименование органов власти, содержащая угрозы и другие проявления (ст. 39), - хотя и указана в качестве возможного основания уголовной ответственности, но таковой не влечёт в силу отсутствия соответствующего состава преступления в УК КНР. В то же время ст. 222 УК КНР предусматривается уголовная ответственность рекламодателя, рекламного агента или рекламного издателя, незаконно использовавших рекламу для сообщения ложной рекламной информации о товаре или услуге, при отягчающих обстоятельствах, при этом общие признаки данного деяния как преступления содержатся в ст. 37 Закона «О рекламе».

Помимо этого УК КНР устанавливает уголовную ответственность за незаконное использование торговой марки (ст. 213), продажу товаров с поддельными торговыми марками (ст. 214), подделку, изготовление или реализацию символики с чужими торговыми марками (ст. 215), подделку чужого патента (ст. 216), посяга- 
тельства на чужие авторские права с целью извлечения прибыли (ст. 217), посягательства на коммерческую тайну (ст. 219), посягательство на коммерческую репутацию лица или товара (ст. 221), сговор о цене на торгах между участниками торгов (ч. 1 ст. 223) или между участниками торгов и организатором торгов (ч. 2 ст. 223 ).

Составы перечисленных преступлений не имеют признаков ограничения конкуренции, но все они характеризуются экономической природой их объекта и предмета, которую законодатель отразил через включение этих преступлений в гл. 3 «Преступления, связанные с нарушением экономического порядка социалистического рынка». Составы преступлений сформулированы как материальные, предусматривающие в качестве последствий значительный ущерб (ст. 219), вред репутации, убытки третьим лицам (ст. 221), нарушение интересов организатора торгов или иных участников торгов (ст. 223). В качестве субъекта ответственности привлекаются не только физические, но и юридические лица.

Весьма интересным и показательным является содержание уголовно-правовой нормы, включённой в ст. 406 УК КНР. Данная статья влечёт уголовную ответственность работников государственных органов, которые при подписании или в процессе исполнения контракта в результате своей вопиющей безответственности стали жертвой мошенничества, если указанные действия причинили серьёзный ущерб государственным интересам. Представляется возможным допустить, что под данную безответственность могут попасть действия указанных лиц, действующих в качестве заказчиков при подписании контракта по итогам проведения неконкурентных торгов с лицом, неправомерно их выигравшим в результате сговора о цене.

УК КНР претерпел ряд изменений, в числе которых следует отметить актуальные и для российского правоприменения тенденции. Так, поправками № 8 в ст. 226 «Принуждение к сделке или к отказу от её совершения» введена уголовная ответственность за принуждение других лиц принимать участие в конкурсе, торгах или выходить из них [22, с. 222]. Помимо этого увеличено число преступлений, субъектом которых могут быть юридические лица (корпорации) [22, с. 224]. Так, юридическое лицо является субъектом преступлений, образующих все формы недобросовестной конкуренции, таких как посягательства на исключительные права конкурента в отношении отдельных объектов интеллектуальной собственности (ст. ст. 213-219 гл. 3), деловую репутацию, ложная реклама, сговор на торгах, принуждение к сделке (ст. ст. 221, 222, 223, 226 гл. 3). Совершение юридическим лицом указанных преступлений влечёт уголовную ответственность в виде штрафов (ст. 220 и 231 УК КНР).

Таким образом, антимонопольное законодательство КНР, активно развиваясь, пока является близким по своей природе европейскому конкурентному праву и в целом содержит традиционные правила противодействия ограничению конкуренции. В то же время оно имеет общие черты и с российским правом, в сравнении с 
которым китайская уголовно-правовая модель охраны конкуренции выглядит более прогрессивной. Анализ УК КНР указывает на его антикоррупционную направленность, одним из элементов которой следует признать уголовную ответственность за сговор на торгах между участником и организатором торгов.

Вышеизложенное позволяет констатировать наличие в рассматриваемых странах развитой системы уголовно-правовых механизмов противодействия антимонопольным нарушениям и недобросовестной конкуренции. Законодательство Япония, Республики Корея и КНР о защите конкуренции содержит как довольно жёсткие правила, заключающиеся в широком перечне оснований уголовной ответственности, достаточно строгих наказаниях, в т. ч. в виде лишения свободы на длительные сроки, привлечении в качестве субъектов не только физических, но и юридических лиц, так и доступные для применения программы смягчения ответственности, содержание которых меняется в целях достижения оптимального баланса между частными и публичными интересами.

\section{Список литературы}

1. Певзнер, Я. Куда движется японская экономика? О книге Michael Porter, Hirotaka Takeuchi, Mariko Sakakibara «Can Japan Compete?» (Может ли Япония конкурировать?): Perseus Publishing, Massachusetts, 2000 // Проблемы Дальнего Востока. - 2001. - № 4. - С. 64-73.

2. Act on Prohibition of Private Monopolization and Maintenance of Fair Trade : Act № 54 of April 14, 1947. - URL: https://www.jftc.go.jp/en/legislation_gls/a mend ed_ama09/index.html (дата обращения: 26.04.2020). - Доступ с официального сайта Комиссии по справедливой торговле Японии.

3. Закон Японии «О предотвращении недобросовестной конкуренции» № 47 от 19.05.1993 г. (с изменениями от 1.07.2019 г.) - URL: https://wipolex.wipo.int/ en/text/532884 (дата обращения: 29.10.2019). - Доступ с официального сайта ВОИС.

4. ICN Anti-Cartel Enforcment Template. - URL: https://www.jftc.go.jp/e n/policy_enforcement/cartels_bidriggings/anti_cartel.html (дата обращения: 20.04.2020). Доступ с официального сайта Комиссии по справедливой торговле Японии.

5. Ezaki, S. Cartels 2019: Japan / S. Ezaki, V. Moussis, Y. Usuki, T. Ishida // Law and Practice. - URL: https:/practiceguides.chambers.com/practice-guides/cartels2019/japan (дата обращения: 25.04.2020).

6. Annual Report on Competition Policy Developments in Japan (2017-2018). URL: https://www.jftc.go.jp/en/about_jftc/annual_reports/index_files/AnnualReportFY2017.pdf (дата обращения: 20.04.2020). - Доступ с официального сайта Комиссии по справедливой торговле Японии.

7. Annual Report on Competition Policy Developments in Japan (2015-2016). URL: https://www.jftc.go.jp/en/about_jftc/annual_reports/AnnualReport2015_files/17122 
5_10.pdf (дата обращения: 6.11.2019). - Доступ с официального сайта Комиссии по справедливой торговле Японии.

8. Ishida, H. The Asia-Pacific Antitrust Review 2019. Japan: Cartels / H. Ishida, A. Yamada. - URL: https:/globalcompetitionreview.com/insight/the-asia-pacificantitrust-review-2019/1188996/japan-cartels (дата обращения: 10.10.2019).

9. Уголовный кодекс Японии : Закон №45 от 24.04.1907 г., в ред. закона № 91 от 12.05.1995 г. - URL: https://constitutions.ru/?p=407 (дата обращения: 20.10.2019).

10. Суслина, С. Государственное регулирование экономики: опыт Республики Корея // Проблемы теории и практики управления. - 2003. - № 4. - С. 33-38.

11. Monopoly regulation and fair trade act (Enforcevent date 29.03.2016: Act № 14137, 29.03.2016). - URL: http://www.ftc.go.kr/solution/skin/doc.html?fn=abe6ebfcf fcd366c32a8cb91035bdbee5ad625cdf007b29f88891153490137d1\&rs=/fileupload/data/re sult/BBSMSTR_000000002411/\# (дата обращения: 03.11.2019). - Доступ с официального сайта Комиссии по справедливой торговле Республики Корея.

12. Kim Sang-Jo. The Asia-Pacific Antitrust Review 2019. Korea: Fair Trade Commission. - URL: https://globalcompetitionreview.com/insight/the-asia-pacific-antitru st-review-2019/1188999/korea-fair-trade-commission (дата обращения: 24.04.2020).

13. Choi, J. H. Cartels 2019: South Korea // Law and Practice / J. H. Choi, J. Y. Park, L. Changhun. - URL: https:/practiceguides.chambers.com/practiceguides/comparison/414/2796-2852/5685-5686-5687-5688-5689-5678-5680 (дата обращения: 24.04.2020).

14. Unfair Competition Prevention and Trade Secret Protection Act : Act № 14033 of February 29, 2016. - URL: https://wipolex.wipo.int/en/text/456204 (дата обращения: 10.11.2019). - Доступ с официального сайта ВОИС.

15. Fair Labelling and Advertising Act : enacted by law № 5814 of February 5, 1999, as amended up to Act № 12380 of January 28, 2014. - URL: http://elaw.klri.re.kr/eng_mobile/viewer.do?hseq=33176\&type=sogan\&key=38 (дата обращения: 12.11.2019).

16. Уголовный кодекс Республики Корея / науч. ред. А. И. Коробеев. Санкт-Петербург : Юрид. центр «Пресс», 2004. - 238 с.

17. Закон Китайской Народной Республики «О противодействии монополиям» : принят на 29 заседании Постоянного комитета Всекитайского собрания народных представителей 10 созыва 30.08.2007 г. - URL: https://chinalaw.center/ business_law/china_antimonopoly_law_2007_russian/(дата обращения: 20.04.2020).

18. Закон Китайской Народной Республики «О недобросовестной конкуренции» : принят на 3 заседании Постоянного Комитета ВСНП 8 созыва 2.09.1993 г. - URL: https://online.zakon.kz/Document/?doc_id=30188225 (дата обращения: 10.10.2019). 
19. Закон Китайской Народной Республики «О рекламе» : принят на 10 заседании Постоянного комитета Всекитайского собрания народных представителей 8 созыва 27.10.1994 г. - URL: http://law.uglc.ru/advertisment.htm (дата обращения: 10.10.2019).

20. Закон Китайской Народной Республики «О торговых марках» : принят на 24 заседании Постоянного комитета Всекитайского собрания народных представителей 5 созыва 23.08.1982 г. - URL: https://online.zakon.kz/Document/? doc_id=30481748 (дата обращения: 10.10.2019). - Доступ с официального сайта Комитета по коммерческой работе со странами СНГ Китайско-европейской ассоциации технико-экономического сотрудничества.

21. Уголовный кодекс КНР : принят на 5 сессии Всекитайского собрания народных представителей шестого созыва 14.03.1997 г. - URL: http://ru.chinaembassy.org/rus/zfhz/zgflyd/t1330730.htm (дата обращения: 26.05.2020).

22. Пан Дунмэй. Становление и развитие китайского уголовного законодательства / Пан Дунмэй, Гао Минсюань // Вестник Санкт-Петербургского университета. Сер. : Право. - 2018. - Т. 9, вып. 2. - С. 215-229.

\section{References}

1. Pevzner Ya. Kuda dvizhetsya yaponskaya ekonomika? O knige Michael Porter, Hirotaka Takeuchi, Mariko Sakakibara «Can Japan Compete?» (Mozhet li Yaponiya konkurirovat'?): Perseus Publishing, Massachusetts, 2000 [Where is the Japanese economy heading? About the book «Can Japan Compete?» by Michael Porter, Hirotaka Takeuchi, Mariko Sakakibara (Can Japan compete?): Perseus Publishing, Massachusetts, 2000]. Problemy Dal'nego Vostoka, 2001, no. 4, pp. 64-73.

2. Act on Prohibition of Private Monopolization and Maintenance of Fair Trade: Act No. 54 of April 14, 1947. Available at: https://www.jftc.go.jp/en/legislation_gls/amen ded_ama09/index.html (accessed: 26 April 2020). Access from the official website of the Japan Fair Trade Commission.

3. The Law of Japan «On the Prevention of Unfair Competition» No. 47 of 05/19/1993 (as amended on 07/01/2019). Available at: https://wipolex.wipo.int/en/text/53 2884 (accessed 02 January 2019). Access from the official WIPO website. (In Japan).

4. ICN Anti-Cartel Enforcment Template. Available at: https://www.jftc.go.jp/en/ policy_enforcement/cartels_bidriggings/anti_cartel.html (accessed 20 April 2020). Access from the official website of the Japan Fair Trade Commission.

5. Ezaki S., Moussis V., Usuki Y., Ishida T. Cartels 2019: Japan. Law and Practice. Available at: https://practiceguides.chambers.com/practice-guides/cartels-2019/japan (accessed 25 April 2020).

6. Annual Report on Competition Policy Developments in Japan (2017-2018). Available at: https://www.jftc.go.jp/en/about_jftc/annual_reports/index_files/Ann ualRe- 
portFY2017.pdf (accessed 20 April 2020). Access from the official website of the Japan Fair Trade Commission.

7. Annual Report on Competition Policy Developments in Japan (2015-2016). Available at: https://www.jftc.go.jp/en/about_jftc/annual_reports/AnnualReport201 5_files/171225_10.pdf (accessed 06 November 2019). Access from the official website of the Japan Fair Trade Commission.

8. Ishida H., Yamada A. The Asia-Pacific Antitrust Review 2019. Japan: Cartels. Available at: https://globalcompetitionreview.com/insight/the-asia-pacific-antitrustreview-2019/1188996/japan-cartels (accessed 10 October 2019).

9. The Criminal Code of Japan: Law No. 45 of 04.24.1907, as amended by Law No. 91 of May 12, 1995. Available at: https://constitutions.ru/?p=407 (accessed 20 October 2019). (In Russian).

10. Suslina S. Gosudarstvennoe regulirovanie ekonomiki: opyt Respubliki Koreya [State regulation of the economy: the experience of the Republic of Korea]. Problemy teorii i praktiki upravleniya, 2003, no. 4, pp. 33-38.

11. Monopoly regulation and fair trade act (Enforcevent date 29.03.2016: Act No. 14137, 29.03.2016). Available at: http://www.ftc.go.kr/solution/skin/doc.html?fn=a be6ebfcffcd366c32a8cb91035bdbee5ad625cdf007b29f88891153490137\#d1\&rs=/fileuplo ad/data/result/BBSMSTR_00000000 (accessed 03 November 2019). Access from the official website of the Fair Trade Commission of the Republic of Korea.

12. Kim Sang-Jo. The Asia-Pacific Antitrust Review 2019. Korea: Fair Trade Commission. Available at: https:/globalcompetitionreview.com/insight/the-asia-pacificantitrust-review-2019/1188999/korea-fair-trade-commission (accessed 24 April 2020).

13. Choi J. H., Park J. Y, Changhun L. Cartels 2019: South Korea. Law and Practice. Available at: https://practiceguides.chambers.com/practice-guides/comparison/414/ 2796-2852/5685-5686-5687-5688-5689-5678-5680 (accessed 24 April 2020).

14. Unfair Competition Prevention and Trade Secret Protection Act: Act No. 14033 of February 29, 2016. Available at: https://wipolex.wipo.int/en/text/456204 (accessed 10 November 2019). Access from the official WIPO website.

15. Fair Labeling and Advertising Act: enacted by law No. 5814 of February 5, 1999, as amended up to Act No. 12380 of January 28, 2014. Available at: http://elaw.klri.re.kr/eng_mobile/viewer. do? hseq $=33176 \&$ type $=$ sogan $\&$ key $=38$ (accessed 12 November 2019).

16. Korobeev A. I. Ugolovnyi kodeks Respubliki Koreya [Criminal Code of the Republic of Korea]. St. Petersburg: Legal Center «Press» Publ., 2004. 238 p.

17. Law of the People's Republic of China «On Counteracting Monopolies»: adopted at the 29th meeting of the Standing Committee of the 10th National People's Congress on August 30, 2007 Available at: https://chinalaw.center/business_law/ch ina_antimonopoly_law_2007_russian/(accessed 20 April 2020). (In Russian).

18. Law of the People's Republic of China «On Unfair Competition»: adopted at the 3rd meeting of the NPC Standing Committee of the 8th convocation on September 2, 1993. Available at: https://online.zakon.kz/Document/?doc_id=30188225 (accessed 10 October 2019). (In Russian).

19. Law of the People's Republic of China «On Advertising»: adopted at the 10th meeting of the Standing Committee of the National People's Congress of the 8th convoca- 
tion on October 27, 1994. Available at: http://law.uglc.ru/advertisment.htm (accessed 10 October 2019). (In Russian).

20. Law of the People's Republic of China «On Trademarks»: adopted at the 24th meeting of the Standing Committee of the 5th National People's Congress on 23 August, 1982. Available at: http://www.cniru.ru/gjzlk/shownews.php?lang=ru\&id=55 (accessed 10 October 2019). (In Russian).

21. The Criminal Code of the People's Republic of China: adopted at the 5th session of the National People's Congress of the Sixth Convocation on March 14, 1997. Available at: http://ru.china-embassy.org/rus/zfhz/zgflyd/t1330730.htm (accessed 26 May 2020). (In Russian).

22. Pan Dongmei, Gao Mingxuan. Stanovlenie i razvitie kitaiskogo ugolovnogo zakonodatel'stva [Formation and Development of Chinese Criminal Law]. Vestnik SanktPeterburgskogo universiteta. Ser.: Pravo. [Bulletin of St. Petersburg University. Ser.: Law], 2018, vol. 9, no. 2, pp. 215-229. 